\title{
Health Status and the Allocation of Time
}

\author{
Melinda Podor ${ }^{*}$ \\ Department of Economics \\ University of Hawai'i at Mānoa \\ and \\ Timothy J. Halliday ${ }^{\dagger}$ \\ Department of Economics \\ University of Hawai' $i$ at Mānoa \\ and the Institute for the Study of Labor (IZA)
}

Working Paper No. 09-7

August 5, 2009

\begin{abstract}
In this paper, we quantify the effects of health on time allocation. We estimate that improvements in health status have large and positive effects on time allocated to home and market production and large negative effects on time spent watching TV, sleeping, and consuming other types of leisure. We find that poor health status results in about 300 additional hours allocated to unproductive activities per year. Plausible estimates of the cost of this lost time exceed $\$ 10,000$. We also find that, for men, better health induces a substitution of market-produced goods for home-produced goods. Particularly, each additional minute spent in home production saves $\$ 0.37$.
\end{abstract}

Keywords: I1, J2

JEL codes: Labor Supply, Time Allocation, Health

\footnotetext{
* Graduate Student, University of Hawaii at Manoa

${ }^{\dagger}$ Assistant Professor, University of Hawaii at Manoa and IZA. Corresponding Author. E-mail: halliday@hawaii.edu. Address: 2424 Maile Way; 533 Saunders

Hall; Honolulu, HI 96822. Tele: (808) 956 - 8615.

* We would like to thank Dan Hamermesh for useful comments.
} 


\section{Introduction}

Illness necessitates time. Clearly, sickness impedes a person's ability to work both at formal jobs and at home, as it requires time to convalesce and to obtain medical care. For this reason, economists dating back to at least Grossman (1972) have considered lost time as one of the major costs of illness. Moreover, adding to these costs is that time lost due to sickness might cause individuals to substitute goods produced on the market for goods produced at home. There have been many attempts in the literature to assess the impact of poor health on one key aspect of time allocation labor supply (e.g. Coile 2004, Smith 1999, Wu 2003, Rust and Phelan 1997, Bound 1991). However, there have been few (if any) attempts to quantify the effects of health status on all aspects of time allocation as well as its effects on the substitution between market and home produced goods.

We attempt to fill this void in this paper. We first conduct a simple accounting exercise in which we conduct a careful descriptive analysis of the effects of health status on time allocation. To do this, we employ two data sources: the American Time Use Survey (ATUS) and the Health and Retirement Survey (HRS). We use 
both of these sources to investigate the relationship between health status and timeuse. We then supplement this analysis by testing whether or not illness induces a substitution of market-produced goods for home-produced goods using consumption data from the HRS.

The balance of this paper is organized as follows. In section 2 , we provide a simple theoretical framework. In Section 3, we describe our data sources. In Section 4, we present our empirical results. In the last section, we conclude.

\section{Theoretical Framework}

We lay out a simple conceptual framework in which we model some of the key tradeoffs that an individual faces using a simple model of time allocation a la Becker (1965) and Gronau (1980). Note that we do not model the joint decisions of married couples and, as in Chapter 1 of Deaton and Muellbauer (1980), we do not model preferences. Our goal is to provide a loose structure that will help us to interpret our empirical findings.

Time allocation depends on a continuous and exogenous measure of health status, $H \in[0, \infty)$. By assumption, healthier people have higher values of $H$. Individuals have an endowment of time that is normalized to unity and allocated across four 
activities: leisure (denoted by $l(H)$ ), home production $(h(H)$ ), market production $(n(H))$, and sick time $(s(H))$. Each activity is a function of health status. Sick time is assumed to be decreasing in health status i.e. $\frac{\partial s}{\partial H}<0$. The time constraint is then given by

$$
l(H)+h(H)+n(H)+s(H)=1 .
$$

Following Grossman (1972), we assume that $\lim _{H \rightarrow 0} s(H)=1$ and $\lim _{H \rightarrow \infty} s(H)=0$, so that those who are in perfect health can allocate their entire time endowment to productive activities or leisure. On the other hand, people who are in extremely poor health will not have any time available for productive activities or leisure. If we differentiate the time constraint evaluated with respect to health status, we obtain

$$
\frac{\partial l}{\partial H}+\frac{\partial h}{\partial H}+\frac{\partial n}{\partial H}+\frac{\partial s}{\partial H}=0
$$

This accounting identity states that if agents allocate more time to one activity then they must subtract the same amount of time from another. It is very similar to the homogeneity restrictions that are imposed on demand functions by the budget constraint (see p. 15-6 of Deaton and Muellbauer 1980).

The household requires an optimal amount $R$ of household services which can either be produced at home or purchased on the market. As in Cortes and Tesada 
(2009), household services in excess of $R$ produce no marginal benefit. The home production technology is denoted by $f(h(H))$ and is increasing and concave. We denote household services consumed on the market by $x(H)$. Consequently, we will have that

$$
x(H)+f(h(H)) \leq R .
$$

If (3) binds and we differentiate it respect to $H$, we obtain that

$$
\frac{\partial x}{\partial H}+\frac{\partial h}{\partial H} f^{\prime}(h(H))=0 \Leftrightarrow \frac{\partial x}{\partial h}=-f^{\prime}(h(H))
$$

This equation demonstrates that, for households that are consuming the optimal amount of household services $(R)$, there will be a trade-off between time spent in home production and consumption of household services on the market. In particular, the marginal rate of substitution between the two is given by the marginal product of home production. Note that this condition need not hold for people who consume less than the optimal amount of household services, since increases in the left-hand side of (3) could now yield a marginal benefit. For example, people who are liquidity constrained may consume less than $R$ and so less sick time may result in more market and home production as well as more consumption of household services. 


\section{Data Description}

Our primary data source is the American Time Use Survey (ATUS) which we use to obtain time-use data. For the years 2006 and 2007, the ATUS has an Eating and Health Module that contains a question about the respondent's general health status and contains about 25,200 people. As we do not model the interactions between spousal health and own time-use (and vice versa), we restrict our analysis to singles. This further restricts the sample to about 10,000: 3651 males and 6353 females. These sample sizes are slightly reduced in our regressions due to missing data. The ATUS over-samples weekends, so that $10 \%$ of the sample is allocated to each weekday and $25 \%$ is allocated to each weekend day. This is done uniformly throughout the year. With weighting, the data are representative of person-days per year.

The ATUS uses a diary to measure time-use in which people list their activities over a 24 hour period. These activities are placed into categories which are then used to construct time-use variables. Activities which could not be easily categorized are assigned to unclassified time. We partition total time allocation into ten categories: home work, paid work, sleep, sleeplessness, watching TV, leisure excluding TV watching, exercise, grooming and personal health care, other time, and unclassified time. We describe the activities that constitute each category in Table 1. Descriptive statistics are provided in Table 2. Note that all time-use categories 
sum to 1440 minutes, the total number of minutes in a day.

We also use variables for health status, race, education, age and number of children. Descriptive statistics for these are reported in Table 2 for ATUS. Our health variable is a self-reported health status variable (SRHS) in which respondents rate their own health in one of five categories: poor $(\mathrm{SRHS}=5)$, fair $(\mathrm{SRHS}=4)$, good $($ SRHS $=3)$, very good $($ SRHS $=2)$, or excellent $($ SRHS $=1)$. While SRHS is subjective, it has consistently been shown to be highly correlated with morbidity and highly predictive of mortality in the PSID (see Halliday 2007 and Smith 2004, for example). For the balance of this paper, we define "good health" to be SRHS equal to 1 or 2 and "bad health" to be SRHS to be equal to 4 or 5 .

Using self-reported, subjective health measures raises issues about the quality of our health measure. However, Bound (1991) investigated the impacts of objective and subjective health measures on estimates of the effects of health on retirement and concluded that the subjective measures actually performed quite well and that the objective measures were actually not without flaws. In addition, Baker, Stabile and Deri (2004) investigated the possibility of measurement errors in self-reported objective measures of health (such as those from the HRS) by comparing them to medical records. They concluded that these measurement errors were often quite large and regrettably correlated with labor market activity. Finally, another ad- 
vantage of self-rated subjective measures over their objective counterparts is that they allow one to gauge the severity of the totality of health conditions, whereas objective measures do not. For example, for some the onset of osteoarthritis may be a harbinger of death, whereas for others it leads to a modification of life-style and noninvasive treatments which allow the person to cope with the condition with a smaller effect on their over-all health status. However, while we generally do believe that SRHS measures are of high quality, we also use self-reported, objective health measures from the HRS for some of our time-use results.

To supplement the analysis, we use the Health and Retirement Survey and its biannual Consumption and Activities Mail Survey (CAMS). CAMS is mailed to a subsample of HRS participants, and is available for 2001, 2003, 2005, and 2007 and contains information on time-use and household spending. We only use the last three periods due to the fact that the 2001 data does not have categories for spending on housekeeping and yard services. There are about 2000 singles present in these years of the panel, $2 / 3$ of which are female. Once again, the sample size is further reduced in our regressions due to missing data in several categories. We also employ time-use data in which the respondent reports the total number of hours in a week allocated to an activity. A summary of these activities is provided in Table 1. Because time diaries were not used in the data collection, the categories need 
not sum to 168 . As the time-use data are of much higher quality in the ATUS, we consider the results from the ATUS to be superior. In addition, we employ information on health outcomes from the HRS including: SRHS and indicators for high blood pressure, diabetes, cancer, lung disease, heart disease, stroke, psychiatric problems, and arthritis. Finally, we also employ data on race, education, age, and number of children. Summary statistics are presented in Table 3.

\section{Empirical Results}

We now discuss our empirical results. The next sub-section presents a non-parametric analysis in which we graphically describe the relationship between time-use, health, and age in the ATUS. We then move on to a semi-parametric regression analysis where we estimate the effects of health status on time-use while controlling for confounding factors using both the ATUS and the HRS. After that, we investigate the substitution of market-produced for home-produced goods. We conclude with a back-of-the-envelope calculate where we compute the cost of lost time.

\subsection{Non-Parametric Analysis of Time-Use}


In Figure 1, we display the relationship between minutes allocated to nine activities (home production, market production, sleep, sleeplessness, TV watching, leisure, grooming and personal health care, and other time-uses) and health status. These can be interpreted as non-parametric regressions since we have a discrete independent variable. We see that declining health is associated with fewer minutes allocated to both home and market production, but the relationship is steeper for the latter. The hours that are lost in these two activities due to illness tend to be allocated to sleeplessness, sleep, and TV watching. We also see that declining health is associated with less time exercising but more time grooming. We obtain the latter result because what we call "grooming" also includes managing a medical condition.

This figure raises an interesting issue in that what we call "sick time" in the theoretical model gets assigned to different variables in the data. Indeed, there is no activity called "sick time" in the ATUS. Rather, what we observe is that the empirical equivalent to sick time is probably classified within the categories of sleep, sleeplessness, and TV watching. These three activities are more common among people with lower health status which is consistent with the assumptions of our theory. Alas, a major problem with the empirical implementation of time-use models is that the delineation across time-use categories is much cleaner in the theory than it is in the data. 
In Figures 2, we explore the age-profile of time-use by plotting the life-cycle profiles of time-use. We see that most of the profiles are relatively flat over the life-course. The profiles that do change with age are TV watching, leisure, and market production with the first two of these showing steady increases with age and the last showing steady decreases with age. Not surprisingly, these changes are amplified during the retirement years. This figure suggests that age is an important confounding factor as it is both highly correlated with time-use and health status.

\subsection{Semi-Parametric Analysis of Time-Use}

\subsubsection{In the ATUS}

To address potential confounding factors (particularly age) we consider the following regression model

$$
\text { time }_{i}^{j}=\beta_{0}^{j}+\beta_{1}^{j} G O O D_{i}+\beta_{2}^{j} B A D_{i}+\beta_{3}^{j} X_{i}+u_{i}^{j} \text { for } j \in\{1, \ldots, 10\} .
$$

The dependent variable is minutes per day allocated to one of the ten categories described in the previous section. The variables $G O O D_{i}$ and $B A D_{i}$ are dummy variables indicating SHRS equal to one or two or SRHS equal to four or five, respectively. The middle SRHS is omitted. We also include $X_{i}$ which is a vector of 
exogenous controls including dummies for age, race, education, and children being present at home, as well as an interaction between SRHS and the children dummy. ${ }^{1}$ Finally, we note that our liberal inclusion of dummy variables for discrete regressors lends a semi-parametric interpretation to the analysis in this sub-section.

The identification strategy that this estimation equation employs is simple: estimate the effects of health status on time-use while controlling for confounding exogenous characteristics using linear regression and a flexible parameterization of the regression function. We are careful not to include any characteristics that are jointly determined with time-use on the right-hand side of the equation such as labor force participation. Provided that the control vector is sufficient, this should address concerns about omitted variables. We do not, however, address possible simultaneity between time-use and health using instrumental variables. While we concede that this is a potential pitfall of our analysis, we would argue that instrumental variables come with many disadvantages that are apt to out-weigh any pitfalls associated with our simple strategy including: (1) weak instruments, (2) difficulty finding instruments that convincingly satisfy exclusion restrictions, and (3) problems with the narrow interpretation of local average treatment effects.

\footnotetext{
${ }^{1}$ The inclusion of the interaction term address the possibility that the effects of having chilren might vary by health status. For example, child rearing might be more time consuming for people who are in poor health. Finally, note that we interact the number of children with the five-point SRHS variable - not $G O O D_{i}$ or $B A D_{i}$. This decision did impact our conclusions in any way.
} 
In Table 4, we report equation-by-equation OLS estimation of the system described by equation (5) including the coefficient estimates of the control variables for the entire ATUS sample of singles. While this is not our preferred estimation method (as it is not as efficient as Seemingly Unrelated Regressions (SUR)) it does illustrate some interesting properties of the ATUS data that cannot be seen using SUR. ${ }^{2}$ First, consistent with the theory, we see that the estimates of $\beta_{1}^{j}$ (the coefficients on bad health) sum exactly to zero. Second, we see that the estimates of $\beta_{0}^{j}$ (the constants) sum to exactly 1440 . The key point is that since the time-use categories sum to 1440 for all individuals in the ATUS, the OLS coefficients on health have to sum to zero. A similar argument applies to the constant estimates. In this sense, the homogeneity restrictions described above will be automatically satisfied in the ATUS.

In Table 5, we report estimates of equation (5) using SUR. For males (row 1 of Table 5), we see that the bulk of the effects of health are on home and market production, sleep, TV watching, and leisure. Specifically, moving from bad to good health increases home production by 12 minutes, market production by 100 minutes, decreases sleeping time by 45 minutes, TV watching by 55 minutes and other leisure

\footnotetext{
${ }^{2}$ The reason is that equation-by-equation OLS allows us to use all time-use categories (which sum to 1440 for all individuals in the data). Using SUR, we must omit one category to ensure that the covariance matrix of residuals is non-singular. We omit unclassified time.
} 
activities by 25 minutes. These estimates, like all others from the ATUS, are on a per day basis. For females (row 2 of Table 5), we see a similar pattern. Moving from bad health to good health increases home production by 25 minutes and market production by 45 minutes and decreases sleeping by 35 minutes, and TV watching by 50 minutes. Noteworthy in both tables are the effects of health on sleeplessness. For both genders, we see that the coefficients on bad health are approximately 5 minutes. These coefficients are very tightly estimated and total to 35 more minutes of sleeplessness per week.

\subsubsection{In the HRS}

Next, we assess the impact of health status on time-use in the HRS by estimating

$$
\text { time }_{i, t}=\beta_{0}+\beta_{1} G O O D_{i, t}+\beta_{2} B A D_{i, t}+\beta_{3} X_{i, t}+v_{i}+\varepsilon_{i, t} .
$$

The dependent variable is the total number of hours per week allocated to one of the following activities: home work, paid work, sleep, leisure, exercise, grooming and health, and other time-uses. The control variables are the same as in equation (5). Note that, because the HRS is a panel, we decompose the residual into timeinvariant and time-variant components. We used Feasible Generalized Least Squares (FGLS) to estimate the model to account for any correlations within individuals and 
across time which occur through the term $v_{i}$. We did not employ a fixed-effects estimator due to having a small sample size, short panel and noisy data. Under these circumstances, fixed effects estimators perform notoriously poorly (see Deaton 1995, for example).

We report the results in Table 6. The results are similar to those from the ATUS but there are some differences, some of which are notable. First, we see positive effects of better health on home-production for women, but not more men. However, this may be an artifact of the poorer quality of these time-use data and smaller sample sizes. Second, we see significant effects of health on sleeping, but they are the opposite sign as in the ATUS; healthier people sleep less in the HRS. This may be a consequence of having older people in the HRS and having an age-dependent effect of health status on sleep. Third, we see a monotonic, negative effect of health status on grooming and health in the HRS, whereas in the ATUS, we saw a U-shaped relationship. Because we have an older population and, hence, a higher prevalence of medical conditions in the HRS, this suggests that healthier people spend less time coping with health issues at all points in the health distribution.

Next, we report the effects of specific medical conditions on time-use. To do this, we estimate a version of equation (6) that also includes dummies for high blood pressure, diabetes, cancer, lung disease, heart disease, stroke, psychiatric problems, 
and arthritis. The results also include controls for good and bad health, as well as controls for age and demographics. We report the results in Tables 7 and 8 for men and women, respectively.

Looking at Table 7, we see that many of these coefficient estimates are consistent with earlier results from the HRS. For example, the home work results show that 4 out of the 5 significant estimates are negative suggesting that poor health status is associated with less time in home production. We see similar results for paid work (4 out of 5 significant estimates are negative), sleep (3 out of 5 significant estimates are positive), and leisure (5 out of 7 significant estimates are positive). The results for groooming and health are not consistent with the results from Table 6 but do suggest that poor health is associated with more time managing a condition (6 out of 8 significant estimates are positive).

The results for women in Table 8 are less consistent with the earlier time-use results from the HRS. The results for paid work ( 7 out of 7 significant estimates are negative) and leisure (5 out of 6 significant estimates are positive) are. However, the results for home work and sleep show that half of the significant estimates are positive and half are negative. Finally, the results for grooming and health are somewhat consistent with those for men ( 5 out of 8 significant estimates are positive). 


\subsection{The Substitution of Market-Production for Home Pro- duction}

Next, we assess the impact of health status on the consumption of household services using the HRS. To do this, we use FGLS to estimate a similar model to equation (6) except with the total amount of money spent on household services annually as the dependent variable. As before, the control variables are the same as in equation $(5)$.

Table 9 reports the effects of health status on the consumption of household services including: housekeeping, yard services and dining out. For males, combining all three categories, we observe that moving from bad to good health decreases expenditures on total household services by $\$ 1600$ per year. Because we saw that a similar movement in health status increased home production time (row 1, Table 5), there is evidence that, consistent with the theory, healthy men substitute home-produced for market-produced goods. If we use the marginal effect of 12 minutes per day for the effects of health on time spent in home production from Table 5 and equation (4), this implies that each extra minute of home production saves about $\$ 0.37$ in house-

hold services consumed on the market since $\frac{1600}{12 * 365} \approx 0.37$. Interestingly, however, in the second row of the table, we see that, for women, moving from bad to good health actually increases spending on household services by $\$ 260$. Sick women work less 
both at home and in the market and they spend less on household services. As we argued above, this could be consistent with single women having a higher likelihood of being liquidity constrained. Because poor health status reduces working time and, hence, income, it may also reduce consumption of household services if some people do not have sufficient assets to draw upon.

\subsection{The Cost of Lost Time}

The results in this section suggest that another cost of poor health is a reallocation of time away from productive activities and towards unproductive activities - notably, sleep, sleeplessness and TV watching. For men in the ATUS, we estimate that a movement from bad to good health results in 335 additional hours of TV watching, 273 additional hours of sleeping and 30 additional hours of sleeplessness per year. For women in the ATUS, we estimate 304 additional hours of TV watching, 213 additional hours of sleeping and 30 additional hours of sleeplessness per year. If one values the cost of an hour of time at $\$ 20$, then the monetary costs of poor health in terms of lost time are $\$ 12,760$ for men and $\$ 10,940$ for women.

\section{Conclusions}


We considered the effects of health status on time allocation. For men, we estimated that a movement from bad to good health status is associated with 12 additional minutes in home production and 100 additional minutes in market production per day. For women, a similar movement is associated with 25 additional minutes in home production and 45 additional minutes in market production. This time, by and large, is taken away from TV watching (55 minutes for men and 50 minutes for women), sleeping (45 minutes for men and 35 minutes for women) and leisure excluding TV watching (55 minutes for men). In addition, poor health exerts a strongly significant but small effect on sleeplessness for both genders. Overall, a major cost of poor health is a movement from productive activities towards unproductive activities. Our finding that poor health encraoaches upon productive time is consistent with results in Hamermesh and Lee (2007) who show that poor health is associated with greater feelings of being under time pressure. A back-of-the-envolope calculation suggests that these costs could amount to over $\$ 10,000$ per year. Finally, we estimated that, for men, better health status results in less money spent on market produced household services. Particularly, each minute of time that is gained due to an improvement in health status saves $\$ 0.37$.

One weakness of this paper is that the analysis is descriptive. We carefully measure partial correlations using two interesting datasets and interpret them in the light 
of a loose theoretical framework. We do not, however, appeal to quasi-experimental methods. This was deliberate. We view this as a largely under-researched topic and, to date, no researchers have produced an analysis which provides a description of how health and time-use are related for a broadly defined population. As we mentioned above, our paper is intended to fill this void. That said we believe that a fruitful avenue for future work is to employ quasi-experimental methods to assess the effects of health on time-use.

\section{References}

[1] Baker M, Stabile M, Deri C. What Do Self-Reported Objective Measures of Health Measure? Journal of Human Resources 2004; 39: 1067-1093.

[2] Becker G. A Theory of the Allocation of Time. Economic Jounal 1965; 75: 492517.

[3] Bound J. Self-Reported Versus Objective Measures of Health in Retirement Models. Journal of Human Resources 1991; 26: 106-38.

[4] Coile C. Health Shocks and Couples' Labor Supply Decisions. NBER Working Paper 2004. 
[5] Cortes P, Tesada J. Low Skilled Immigration and the Labor Supply of Highly Educated Women. unpublished mimeo 2009.

[6] Deaton A, Muellbauer J. Economics and Consumer Behavior 1980; Cambridge Press: Cambridge.

[7] Deaton A. Data and Econometric Tools for Development Analysis, in Handbook of Development Economics Vol. 3A, eds. Behrman, J and Srinivasan, TN. 1995. North-Holland: Amsterdam.

[8] Gronau R. Home Production: A Forgotten Industry. Review of Economics and Statistics 1980; 62: 408-416.

[9] Grossman M. On the Concept of Health Capital and the Demand for Health. Journal of Political Economy 1972; 80: 223-255.

[10] Halliday T. Income Volatility and Health. unpublished mimeo 2007.

[11] Hamermesh D and Lee J. Stressed Out in Four Continents: Time Crunch or Yuppie Kvetch? Review of Economics and Statistics 2007; 89: 374-383.

[12] Rust J, Phelan C. How Social Security and Medicare Affect Retirement Behavior in World of Incomplete Markets. Econometrica 1997; 65: 781-831. 
[13] Smith J. Healthy Bodies and Thick Wallets: The Dual Relationship between Health and Economic Status. Journal of Economic Perspectives 1999; 13: 14566.

[14] Smith J. Health and SES Over the Life-Course, unpublished mimeo, 2004.

[15] Wooldridge J. Econometric Analysis of Cross-Sectional and Panel Data 2003; MIT Press: Cambridge, MA.

[16] Wu S. The Effects of Health Events on the Economic Status of Couples. Journal of Human Resources 2003; 38; 219-30. 
Figure 1: Average time spent with various activities depending on health status
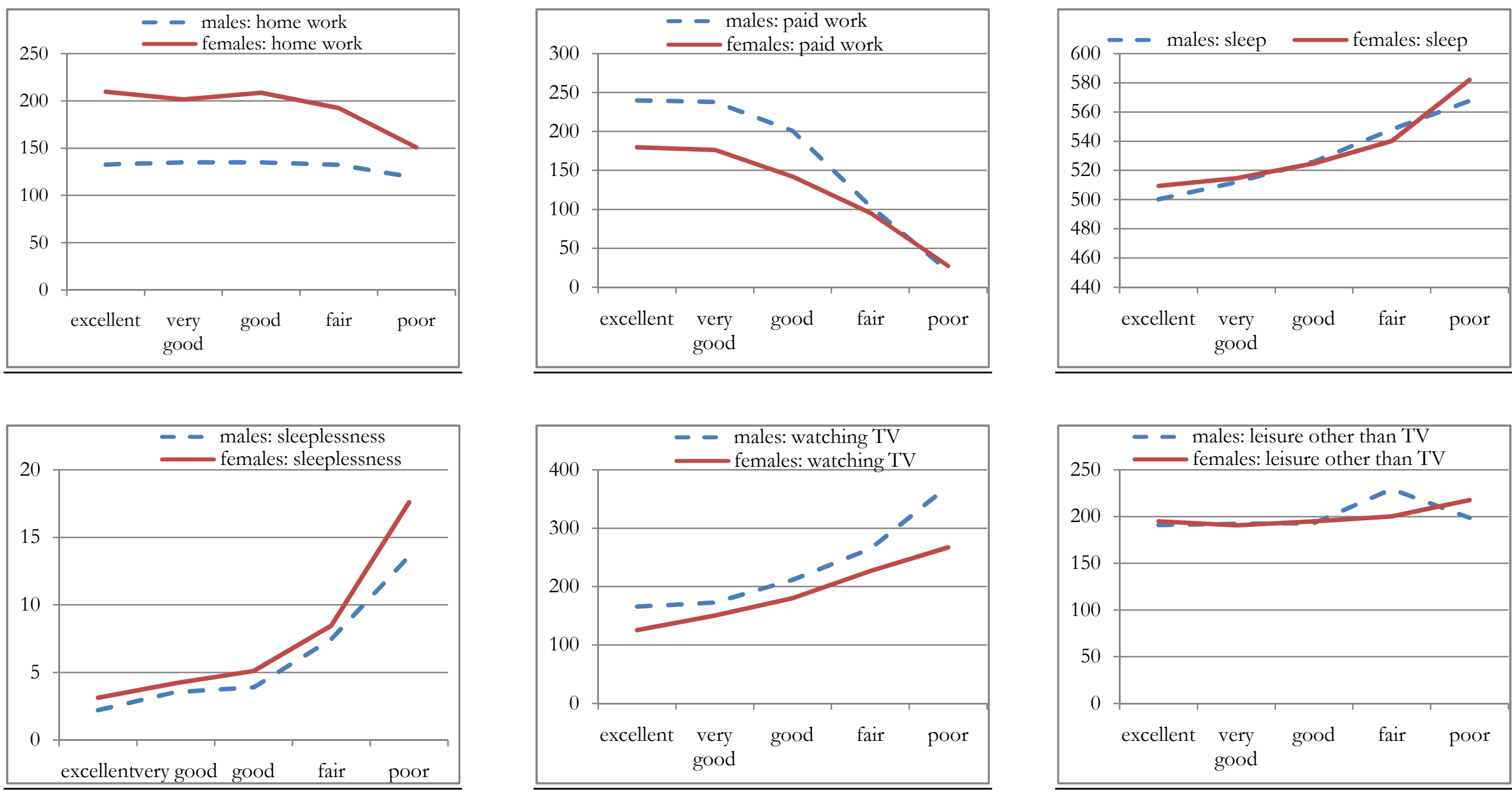

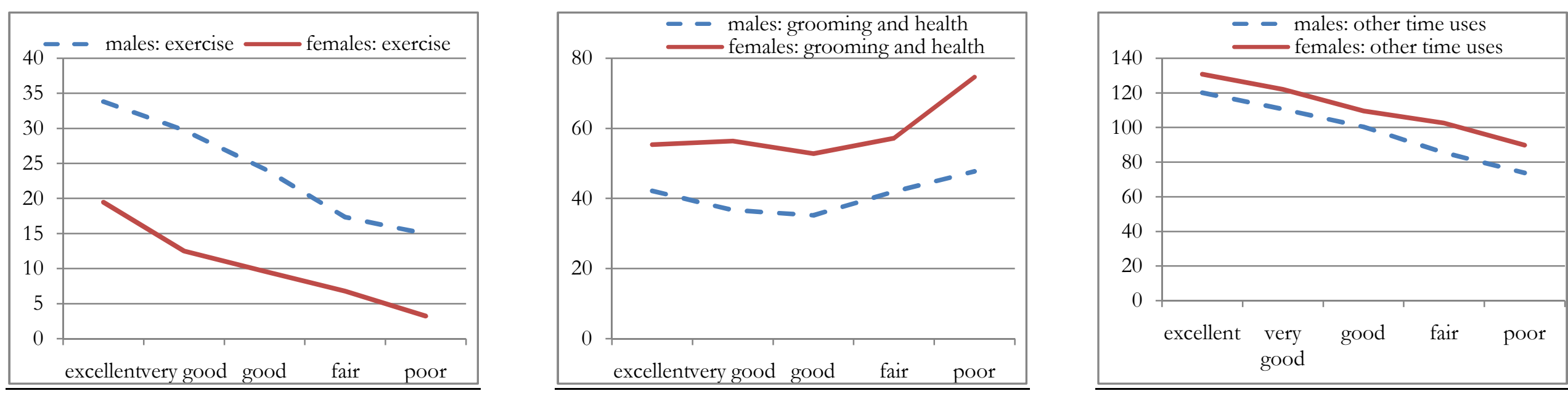

Note: The horizontal axes denote self-reported health status. Grooming also includes time spent managing health conditions. 
Figure 2: Minutes per day spent with various activities by age, using ATUS data

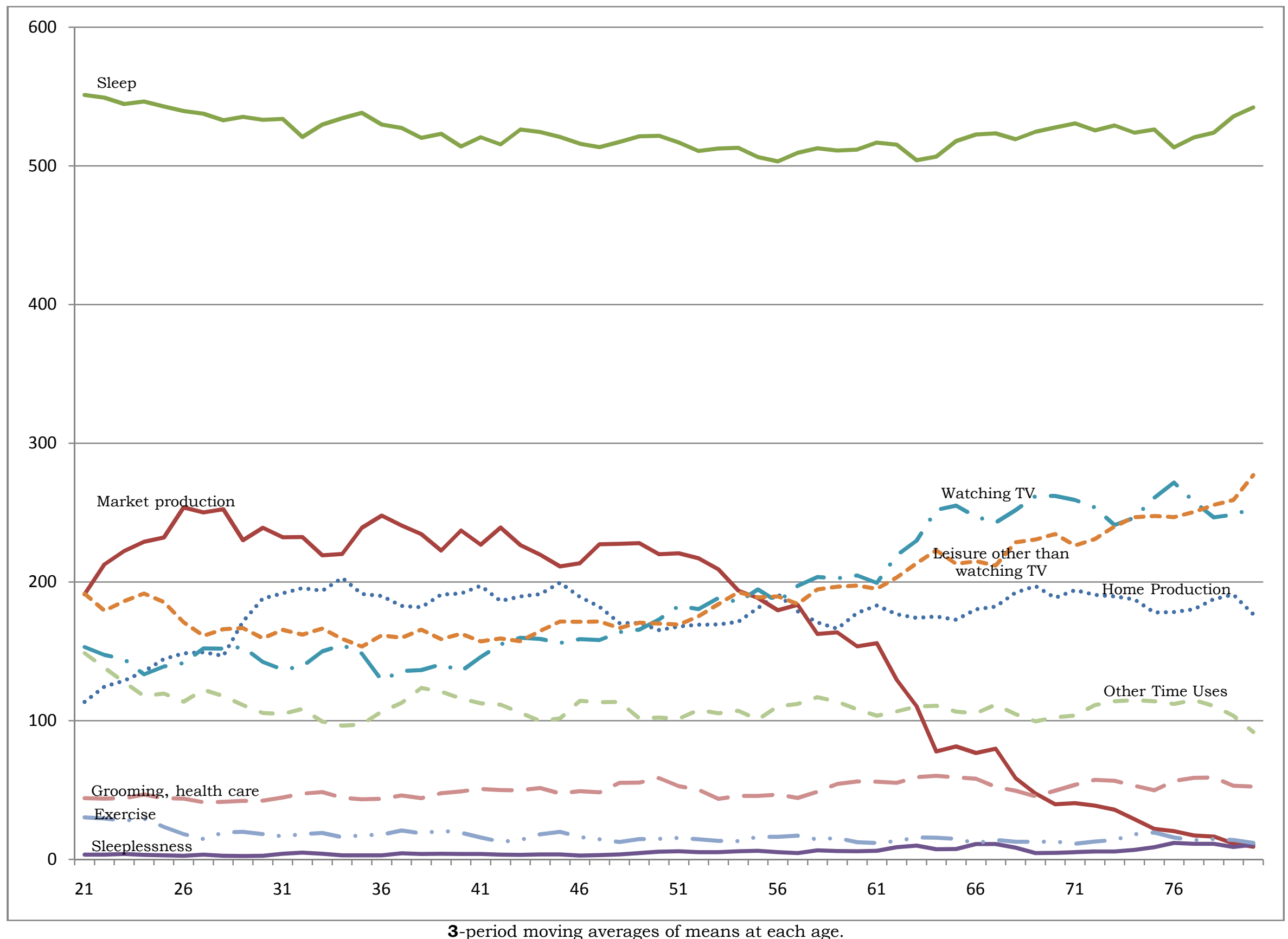

3-period moving averages of means at each age. 
Table 1: Description of time use variables in ATUS and HRS

\begin{tabular}{|c|c|c|c|}
\hline & Both & $\begin{array}{l}\text { ATUS only } \\
\end{array}$ & HRS only \\
\hline Home work & $\begin{array}{l}\text { Meal preparation and cleanup } \\
\text { House cleaning } \\
\text { Laundry } \\
\text { Shopping } \\
\text { Home repair and maintenance } \\
\text { Gardening } \\
\text { Pet care } \\
\text { Household management/bookkeeping } \\
\text { Vehicle care }\end{array}$ & $\begin{array}{l}\text { Child and adult care of household members } \\
\text { Appliance care } \\
\text { Sewing } \\
\text { Related travel to all }\end{array}$ & \\
\hline Paid work & Work at a paid job & $\begin{array}{l}\text { Waiting, socializing, eating associated with } \\
\text { working, } \\
\text { Other Income-generating Activities, } \\
\text { Job Search and Interviewing }\end{array}$ & \\
\hline Sleep & Time spent sleeping & & \\
\hline Sleeplessness & & Time spent not being able to sleep & \\
\hline $\begin{array}{l}\text { Leisure } \\
\text { (Note: in ATUS we } \\
\text { separate } \\
\text { watching TV from } \\
\text { other types of } \\
\text { leisure) }\end{array}$ & $\begin{array}{l}\text { Watching TV, Listening to music } \\
\text { Playing cards, games, puzzles } \\
\text { Using computer (for leisure: ATUS) } \\
\text { Arts and crafts } \\
\text { Reading } \\
\text { Concerts, movies, lectures } \\
\text { Singing, playing instrument }\end{array}$ & $\begin{array}{l}\text { Eating and drinking } \\
\text { Socializing and communicating } \\
\text { Attending \& hosting events } \\
\text { Relaxing } \\
\text { Hobbies } \\
\text { Attending performances, movies, casinos }\end{array}$ & $\begin{array}{l}\text { Leisure dining and eating out } \\
\text { Phone, letters, emails } \\
\text { Praying and meditating }\end{array}$ \\
\hline Exercise & Sports and Exercise & & \\
\hline Grooming & $\begin{array}{l}\text { Personal grooming other than sleep } \\
\text { Health-related self care }\end{array}$ & Personal activities & \\
\hline Other time uses & $\begin{array}{l}\text { Helping non-family } \\
\text { Volunteering } \\
\text { Religious and spiritual time }\end{array}$ & $\begin{array}{l}\text { Education } \\
\text { Using professional services } \\
\text { Using government services } \\
\text { Travel time other than related to household } \\
\text { production } \\
+ \text { all other time uses not included above }\end{array}$ & $\begin{array}{l}\text { Visiting in person } \\
\text { Showing affection } \\
\text { Attending meetings }\end{array}$ \\
\hline $\begin{array}{l}\text { Unclassified } \\
\text { time }\end{array}$ & & $\begin{array}{l}\text { Respondent refusal } \\
\text { Respondent can't remember } \\
\text { Unable to code }\end{array}$ & \\
\hline
\end{tabular}


Tables 2: Summary statistics, singles over 20 years old, using ATUS data

MALES

\begin{tabular}{|c|c|c|c|c|c|c|c|c|c|c|}
\hline & $\begin{array}{c}\text { Home } \\
\text { work }\end{array}$ & $\begin{array}{c}\text { Paid } \\
\text { work }\end{array}$ & Sleep & $\begin{array}{c}\text { Sleepless } \\
\text {-ness }\end{array}$ & $\begin{array}{l}\text { Watch- } \\
\text { ing TV }\end{array}$ & $\begin{array}{c}\text { Leisure } \\
\text { (exc. TV) }\end{array}$ & Exercise & $\begin{array}{c}\text { Groom- } \\
\text { ing }\end{array}$ & $\begin{array}{c}\text { Other } \\
\text { time }\end{array}$ & $\begin{array}{l}\text { Total } \\
\text { time* }\end{array}$ \\
\hline Num. of Observations & 3651 & 3651 & 3651 & 3651 & 3651 & 3651 & 3651 & 3651 & 3651 & 3651 \\
\hline Mean & 132.04 & 193.49 & 523.14 & 4.57 & 209.51 & 408.16 & 25.90 & 38.81 & 91.26 & 1440.00 \\
\hline \multirow[t]{2}{*}{ Standard Deviation } & 153.79 & 259.39 & 149.68 & 29.22 & 201.57 & 233.14 & 76.07 & 68.10 & 120.21 & 0.00 \\
\hline & Age & $\begin{array}{c}\text { Good } \\
\text { health }\end{array}$ & $\begin{array}{c}\text { Bad } \\
\text { health }\end{array}$ & Black & $\begin{array}{l}\text { Other } \\
\text { race } \dagger\end{array}$ & Hispanic & $\begin{array}{c}\text { Less } \\
\text { than HS } \\
\end{array}$ & $\begin{array}{c}\text { Any } \\
\text { college }\end{array}$ & $\begin{array}{c}\text { Grad } \\
\text { degree }\end{array}$ & $\begin{array}{c}\text { Any } \\
\text { children }\end{array}$ \\
\hline Num. of Observations & 3651 & 3601 & 3601 & 3651 & 3651 & 3651 & 3651 & 3651 & 3651 & 3651 \\
\hline Mean & 47.70 & 0.49 & 0.21 & 0.18 & 0.04 & 0.14 & 0.14 & 0.47 & 0.09 & 0.15 \\
\hline Standard Deviation & 17.53 & 0.50 & 0.41 & 0.38 & 0.20 & 0.35 & 0.35 & 0.50 & 0.28 & 0.36 \\
\hline
\end{tabular}

FEMALES

\begin{tabular}{|c|c|c|c|c|c|c|c|c|c|c|}
\hline & $\begin{array}{c}\text { Home } \\
\text { work }\end{array}$ & $\begin{array}{l}\text { Paid } \\
\text { work }\end{array}$ & Sleep & $\begin{array}{c}\text { Sleepless } \\
\text {-ness }\end{array}$ & $\begin{array}{l}\text { Watch- } \\
\text { ing TV }\end{array}$ & $\begin{array}{c}\text { Leisure } \\
\text { (exc. TV) }\end{array}$ & Exercise & $\begin{array}{c}\text { Groom- } \\
\text { ing }\end{array}$ & $\begin{array}{l}\text { Other } \\
\text { time }\end{array}$ & $\begin{array}{l}\text { Total } \\
\text { time* }\end{array}$ \\
\hline Num. of Observations & 6353 & 6353 & 6353 & 6353 & 6353 & 6353 & 6353 & 6353 & 6353 & 6353 \\
\hline Mean & 199.24 & 140.82 & 527.29 & 6.06 & 178.27 & 373.98 & 10.82 & 56.49 & 93.99 & 1440.00 \\
\hline \multirow[t]{2}{*}{ Standard Deviation } & 175.59 & 225.93 & 147.01 & 37.23 & 178.53 & 215.69 & 38.87 & 75.07 & 125.76 & 0.00 \\
\hline & Age & $\begin{array}{c}\text { Good } \\
\text { health }\end{array}$ & $\begin{array}{c}\text { Bad } \\
\text { health }\end{array}$ & Black & $\begin{array}{l}\text { Other } \\
\text { race } \dagger\end{array}$ & Hispanic & $\begin{array}{c}\text { Less } \\
\text { than HS }\end{array}$ & $\begin{array}{c}\text { Any } \\
\text { college }\end{array}$ & $\begin{array}{c}\text { Grad } \\
\text { degree }\end{array}$ & $\begin{array}{c}\text { Any } \\
\text { children }\end{array}$ \\
\hline Num. of Observations & 6353 & 6247 & 6247 & 6353 & 6353 & 6353 & 6353 & 6353 & 6353 & 6353 \\
\hline Mean & 53.57 & 0.43 & 0.25 & 0.22 & 0.04 & 0.12 & 0.15 & 0.46 & 0.09 & 0.31 \\
\hline Standard Deviation & 18.68 & 0.50 & 0.43 & 0.41 & 0.19 & 0.32 & 0.36 & 0.50 & 0.29 & 0.46 \\
\hline
\end{tabular}

*Includes unclassified time (respondent refused, respondent can't remember, or unable to code)

$\dagger$ Individual belonging to a race other than black or white 
Tables 3: Summary statistics, singles, using HRS data

MALES

\begin{tabular}{|c|c|c|c|c|c|c|c|c|c|}
\hline & Home work & Paid work & Sleep & Leisure & Exercise & Health care & Other time & Total time & Age \\
\hline Num. of Observations & 1009 & 1069 & 1074 & 630 & 1057 & 1032 & 1021 & 930 & 917 \\
\hline Mean* & 29.70 & 10.30 & 46.52 & 63.07 & 8.96 & 13.07 & 20.68 & 131.13 & 68.24 \\
\hline Standard Deviation & 29.19 & 18.42 & 19.23 & 40.67 & 11.65 & 39.13 & 26.71 & 72.70 & 10.08 \\
\hline
\end{tabular}

\begin{tabular}{|c|c|c|c|c|c|c|c|c|c|c|}
\hline & Age & $\begin{array}{c}\text { Good } \\
\text { health }\end{array}$ & $\begin{array}{c}\text { Bad } \\
\text { health }\end{array}$ & Black & $\begin{array}{l}\text { Other } \\
\text { race } \dagger\end{array}$ & Hispanic & $\begin{array}{c}\text { Less than } \\
\text { HS }\end{array}$ & $\begin{array}{c}\text { Any } \\
\text { college }\end{array}$ & $\begin{array}{c}\text { Grad } \\
\text { degree }\end{array}$ & $\begin{array}{c}\text { Any } \\
\text { children }\end{array}$ \\
\hline Num. of Observations & 917 & 1102 & 1102 & 1102 & 1102 & 1102 & 1102 & 1102 & 1102 & 1102 \\
\hline Mean & 68.24 & 0.39 & 0.29 & 0.16 & 0.03 & 0.06 & 0.20 & 0.29 & 0.10 & 0.80 \\
\hline Standard Deviation & 10.08 & 0.49 & 0.45 & 0.36 & 0.17 & 0.25 & 0.40 & 0.45 & 0.30 & 0.40 \\
\hline
\end{tabular}

\begin{tabular}{|c|c|c|c|c|c|c|c|c|}
\hline & $\begin{array}{c}\text { high blood } \\
\text { pressure }\end{array}$ & diabetes & cancer & lung disease & heart disease & stroke & $\begin{array}{c}\text { psychiatric } \\
\text { problems }\end{array}$ & arthritis \\
\hline Num. of Observations & 1504 & 1507 & 1508 & 1507 & 1505 & 1502 & 1507 & 1508 \\
\hline Mean $^{* *}$ & 0.50 & 0.17 & 0.14 & 0.12 & 0.25 & 0.09 & 0.13 & 0.53 \\
\hline Standard Deviation & 0.50 & 0.38 & 0.34 & 0.33 & 0.43 & 0.29 & 0.34 & 0.50 \\
\hline
\end{tabular}

\begin{tabular}{|c|c|c|c|c|}
\hline & $\begin{array}{c}\text { Annual spending on } \\
\text { housekeeping services }\end{array}$ & $\begin{array}{l}\text { Annual spending on yard } \\
\text { services }\end{array}$ & $\begin{array}{c}\text { Annual spending on dining } \\
\text { out }\end{array}$ & $\begin{array}{c}\text { Annual spending on all } \\
\text { three categories }\end{array}$ \\
\hline Num. of Observations & 1059 & 1060 & 1427 & 1014 \\
\hline Mean & 313.42 & 193.84 & 294.86 & 2142.01 \\
\hline Standard Deviation & 893.29 & 1041.64 & 873.29 & 3335.09 \\
\hline
\end{tabular}

*Time use variables are hours per week in all HRS data.

**0: does not have condition, 1: has condition

$\dagger$ Individual belonging to a race other than black or white 
Summary statistics, singles, using HRS data

FEMALES

\begin{tabular}{|c|c|c|c|c|c|c|c|c|c|}
\hline & Home work & Paid work & Sleep & Leisure & Exercise & Health care & Other time & Total time & Age \\
\hline Num. of Observations & 3492 & 3780 & 3766 & 2126 & 3630 & 3580 & 3450 & 3031 & 3371 \\
\hline Mean* & 29.92 & 8.66 & 44.98 & 72.63 & 7.34 & 17.45 & 28.24 & 138.41 & 70.52 \\
\hline Standard Deviation & 28.75 & 16.58 & 19.89 & 46.73 & 11.85 & 49.30 & 45.10 & 90.88 & 10.58 \\
\hline
\end{tabular}

\begin{tabular}{|c|c|c|c|c|c|c|c|c|c|c|}
\hline & Age & $\begin{array}{c}\text { Good } \\
\text { health }\end{array}$ & $\begin{array}{c}\text { Bad } \\
\text { health }\end{array}$ & Black & $\begin{array}{l}\text { Other } \\
\text { race } \dagger\end{array}$ & Hispanic & $\begin{array}{c}\text { Less than } \\
\text { HS } \\
\end{array}$ & $\begin{array}{c}\text { Any } \\
\text { college }\end{array}$ & $\begin{array}{c}\text { Grad } \\
\text { degree }\end{array}$ & $\begin{array}{c}\text { Any } \\
\text { children }\end{array}$ \\
\hline Num. of Observations & 3371 & 3882 & 3882 & 3882 & 3882 & 3882 & 3882 & 3882 & 3882 & 3882 \\
\hline Mean & 70.52 & 0.38 & 0.31 & 0.18 & 0.03 & 0.07 & 0.22 & 0.28 & 0.08 & 0.89 \\
\hline Standard Deviation & 10.58 & 0.48 & 0.46 & 0.38 & 0.18 & 0.25 & 0.42 & 0.45 & 0.27 & 0.32 \\
\hline
\end{tabular}

\begin{tabular}{|c|c|c|c|c|c|c|c|c|}
\hline & $\begin{array}{c}\text { high blood } \\
\text { pressure }\end{array}$ & diabetes & cancer & lung disease & heart disease & stroke & $\begin{array}{c}\text { psychiatric } \\
\text { problems }\end{array}$ & arthritis \\
\hline Num. of Observations & 5248 & 5246 & 5248 & 5249 & 5250 & 5211 & 5248 & 5250 \\
\hline Mean $^{* *}$ & 0.58 & 0.16 & 0.15 & 0.13 & 0.24 & 0.06 & 0.21 & 0.69 \\
\hline Standard Deviation & 0.49 & 0.37 & 0.36 & 0.33 & 0.43 & 0.24 & 0.41 & 0.46 \\
\hline
\end{tabular}

\begin{tabular}{|c|c|c|c|c|}
\hline & $\begin{array}{c}\text { Annual spending on } \\
\text { housekeeping services }\end{array}$ & $\begin{array}{l}\text { Annual spending on yard } \\
\text { services }\end{array}$ & $\begin{array}{c}\text { Annual spending on dining } \\
\text { out }\end{array}$ & $\begin{array}{c}\text { Annual spending on all } \\
\text { three categories }\end{array}$ \\
\hline Num. of Observations & 3670 & 3677 & 4944 & 3487 \\
\hline Mean & 392.10 & 342.99 & 127.21 & 1620.64 \\
\hline Standard Deviation & 2373.24 & 1341.35 & 432.85 & 3787.78 \\
\hline
\end{tabular}

*Time use variables are hours per week in all HRS data.

**0: does not have condition, 1: has condition

$\dagger$ Individual belonging to a race other than black or white 
Table 4.

OLS estimates of ATUS data using bad health only.

\begin{tabular}{|c|c|c|c|c|c|c|c|c|c|}
\hline $\begin{array}{c}\text { Dependent variable: } \\
\text { Minutes spent with activity per } 24 \\
\text { hours } \\
\end{array}$ & $\begin{array}{l}\text { Home } \\
\text { Work }\end{array}$ & Paid Work & Sleep & $\begin{array}{l}\text { Sleepless- } \\
\text { ness }\end{array}$ & $\begin{array}{c}\text { Watching } \\
\text { TV }\end{array}$ & $\begin{array}{c}\text { Leisure } \\
\text { (exc. TV) }\end{array}$ & Exercise & $\begin{array}{l}\text { Grooming } \\
\text { and } \\
\text { Health } \\
\end{array}$ & $\begin{array}{l}\text { Other Time } \\
\text { +unclassified }\end{array}$ \\
\hline Bad Health & $\begin{array}{c}-19.38^{* * *} \\
(5.56)\end{array}$ & $\begin{array}{c}-62.33^{* * *} \\
(8.86)\end{array}$ & $\begin{array}{c}33.04 * * * \\
(5.97)\end{array}$ & $\begin{array}{c}4.69 * * * \\
(1.45)\end{array}$ & $\begin{array}{c}43.39 * * * \\
(6.49)\end{array}$ & $\begin{array}{c}8.97 \\
(6.08)\end{array}$ & $\begin{array}{c}-5.02^{* *} \\
(2.00)\end{array}$ & $\begin{array}{c}5.28 * * \\
(2.30)\end{array}$ & $\begin{array}{l}-8.63 \\
(5.31)\end{array}$ \\
\hline Black & $\begin{array}{c}-29.70 * * * \\
(5.26)\end{array}$ & $\begin{array}{c}-15.06^{*} \\
(9.10)\end{array}$ & $\begin{array}{c}17.28^{* * *} \\
(6.18)\end{array}$ & $\begin{array}{l}-0.44 \\
(1.15)\end{array}$ & $\begin{array}{c}29.59 * * * \\
(6.53)\end{array}$ & $\begin{array}{c}-18.99 * * * \\
(5.95)\end{array}$ & $\begin{array}{r}-3.74 * \\
(2.14)\end{array}$ & $\begin{array}{c}12.50^{* * *} \\
(2.55)\end{array}$ & $\begin{array}{c}8.57 \\
(5.40)\end{array}$ \\
\hline Hispanic & $\begin{array}{l}-4.79 \\
(7.11)\end{array}$ & $\begin{array}{c}28.58^{* *} \\
(12.54)\end{array}$ & $\begin{array}{c}17.54 * * * \\
(6.77)\end{array}$ & $\begin{array}{c}-4.21 * * * \\
(1.07)\end{array}$ & $\begin{array}{l}-2.00 \\
(7.03)\end{array}$ & $\begin{array}{c}-28.78^{* * *} \\
(7.66)\end{array}$ & $\begin{array}{l}1.61 \\
(3.43)\end{array}$ & $\begin{array}{l}1.03 \\
(2.62)\end{array}$ & $\begin{array}{l}-8.98 \\
(6.67)\end{array}$ \\
\hline Other Race $\dagger$ & $\begin{array}{r}-14.97 \\
(9.94)\end{array}$ & $\begin{array}{c}0.04 \\
(19.95)\end{array}$ & $\begin{array}{c}7.02 \\
(10.36)\end{array}$ & $\begin{array}{l}3.68^{*} \\
(2.18)\end{array}$ & $\begin{array}{l}-11.30 \\
(10.37)\end{array}$ & $\begin{array}{l}-6.26 \\
(13.46)\end{array}$ & $\begin{array}{l}2.29 \\
(6.12)\end{array}$ & $\begin{array}{l}2.81 \\
(3.67)\end{array}$ & $\begin{array}{c}16.69 \\
(14.02)\end{array}$ \\
\hline Education: less than high school diploma & $\begin{array}{l}-8.63 \\
(7.46)\end{array}$ & $\begin{array}{l}-20.25^{*} \\
(11.39)\end{array}$ & $\begin{array}{c}22.43^{* * * *} \\
(7.32)\end{array}$ & $\begin{array}{l}2.14 \\
(1.91)\end{array}$ & $\begin{array}{c}20.36^{* *} \\
(8.62)\end{array}$ & $\begin{array}{c}1.63 \\
(8.34)\end{array}$ & $\begin{array}{l}-1.52 \\
(3.13)\end{array}$ & $\begin{array}{l}-1.35 \\
(3.20)\end{array}$ & $\begin{array}{c}-14.82 * * * \\
(5.66)\end{array}$ \\
\hline Education: any college & $\begin{array}{l}-5.21 \\
(5.27)\end{array}$ & $\begin{array}{c}21.47^{* *} \\
(8.83)\end{array}$ & $\begin{array}{c}-13.08^{* *} \\
(5.09)\end{array}$ & $\begin{array}{c}-2.54^{* *} \\
(1.05)\end{array}$ & $\begin{array}{c}-41.34 * * * \\
(5.73)\end{array}$ & $\begin{array}{c}11.41^{* *} \\
(5.48)\end{array}$ & $\begin{array}{l}-1.41 \\
(2.35)\end{array}$ & $\begin{array}{l}2.56 \\
(2.41)\end{array}$ & $\begin{array}{c}28.14^{* * *} \\
(5.48)\end{array}$ \\
\hline Education: graduate degree & $\begin{array}{l}-9.36 \\
(7.70)\end{array}$ & $\begin{array}{c}45.33^{* * * *} \\
(12.91)\end{array}$ & $\begin{array}{l}-24.68^{* * *} \\
\quad(6.63)\end{array}$ & $\begin{array}{l}-2.95^{*} \\
(1.67)\end{array}$ & $\begin{array}{l}-84.83 * * * \\
(7.36)\end{array}$ & $\begin{array}{c}24.21 * * * \\
(7.56)\end{array}$ & $\begin{array}{c}7.56 * * * \\
(2.88)\end{array}$ & $\begin{array}{l}4.36 \\
(3.32)\end{array}$ & $\begin{array}{l}40.35^{* * *} \\
(7.61)\end{array}$ \\
\hline Any children & $\begin{array}{c}42.03^{* * *} \\
(12.09)\end{array}$ & $\begin{array}{l}-4.79 \\
(16.54)\end{array}$ & $\begin{array}{l}7.50 \\
(7.39)\end{array}$ & $\begin{array}{l}-0.01 \\
(0.90)\end{array}$ & $\begin{array}{l}-23.91 * * * \\
(7.73)\end{array}$ & $\begin{array}{c}-14.85^{*} \\
(7.99)\end{array}$ & $\begin{array}{r}-5.77 * \\
(3.11)\end{array}$ & $\begin{array}{l}3.04 \\
(3.16)\end{array}$ & $\begin{array}{l}-3.24 \\
(8.02)\end{array}$ \\
\hline $\begin{array}{c}\text { Number of children * Health (interaction } \\
\text { var.) }\end{array}$ & $\begin{array}{c}9.36 * * * \\
(2.61)\end{array}$ & $\begin{array}{l}-3.92 \\
(3.17)\end{array}$ & $\begin{array}{l}-0.55 \\
(1.11)\end{array}$ & $\begin{array}{l}-0.18 \\
(0.14)\end{array}$ & $\begin{array}{l}-0.06 \\
(1.21)\end{array}$ & $\begin{array}{l}-1.44 \\
(1.10)\end{array}$ & $\begin{array}{c}-0.68^{* *} \\
(0.29)\end{array}$ & $\begin{array}{l}-0.26 \\
(0.52)\end{array}$ & $\begin{array}{c}-2.27^{*} \\
(1.22)\end{array}$ \\
\hline Constant & $\begin{array}{c}200.82^{* * *} \\
\quad(22.44)\end{array}$ & $\begin{array}{c}60.82^{* * *} \\
(16.03)\end{array}$ & $\begin{array}{c}527.19^{* * *} \\
\quad(21.05)\end{array}$ & $\begin{array}{c}6.15^{* *} \\
(3.01)\end{array}$ & $\begin{array}{c}309.34^{* * *} \\
(31.74)\end{array}$ & $\begin{array}{c}205.51^{* * *} \\
(17.40)\end{array}$ & $\begin{array}{c}10.26 * * * \\
(2.71)\end{array}$ & $\begin{array}{c}35.90 * * * \\
(5.39)\end{array}$ & $\begin{array}{c}84.00 * * * \\
(11.67)\end{array}$ \\
\hline $\begin{array}{c}\mathrm{N} \\
\mathrm{R} 2\end{array}$ & $\begin{array}{c}9848 \\
0.100\end{array}$ & $\begin{array}{c}9848 \\
0.165\end{array}$ & $\begin{array}{c}9848 \\
0.040\end{array}$ & $\begin{array}{l}9848 \\
0.026\end{array}$ & $\begin{array}{l}9848 \\
0.131\end{array}$ & $\begin{array}{l}9848 \\
0.069\end{array}$ & $\begin{array}{r}9848 \\
0.035\end{array}$ & $\begin{array}{c}9848 \\
0.021\end{array}$ & $\begin{array}{c}9848 \\
0.066\end{array}$ \\
\hline
\end{tabular}

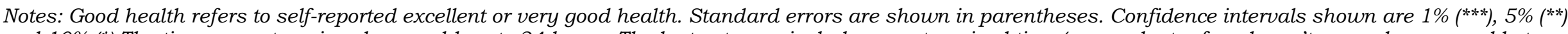

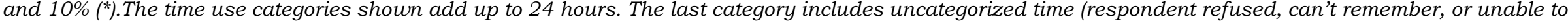

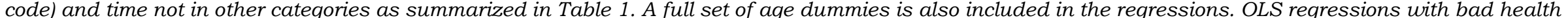
only (or good health only) result in coefficients adding up to zero. Both genders are included in the regression.

$\dagger$ Individual belonging to a race other than black or white 
Table 5: Estimates of the effect of health status on various time use categories using ATUS data

\begin{tabular}{|c|c|c|c|c|c|c|c|c|c|c|c|}
\hline & $\begin{array}{l}\text { Dependent variable: } \\
\text { Minutes spent with } \\
\text { activity per } 24 \text { hours }\end{array}$ & $\begin{array}{l}\text { Home } \\
\text { Work }\end{array}$ & $\begin{array}{l}\text { Paid } \\
\text { Work }\end{array}$ & Sleep & $\begin{array}{l}\text { Sleepless- } \\
\text { ness }\end{array}$ & $\begin{array}{c}\text { Watching } \\
\text { TV }\end{array}$ & $\begin{array}{l}\text { Leisure } \\
\text { (exc. TV) }\end{array}$ & Exercise & $\begin{array}{l}\text { Grooming } \\
\text { and } \\
\text { Health }\end{array}$ & $\begin{array}{l}\text { Other } \\
\text { Time } \\
\text { Uses }\end{array}$ & $\begin{array}{c}\text { Test of } \\
\text { good \& } \\
\text { bad } \\
\text { health } \\
\text { for all eq. }\end{array}$ \\
\hline \multirow{2}{*}{$\begin{array}{l}\text { All single } \\
\text { males, any } \\
\text { survey day }\end{array}$} & Good Health & $\begin{array}{c}10.06 * \\
(5.59)\end{array}$ & $\begin{array}{l}11.00 \\
(9.88)\end{array}$ & $\begin{array}{c}-20.95^{* * *} \\
(5.84)\end{array}$ & $\begin{array}{l}-0.20 \\
(1.00)\end{array}$ & $\begin{array}{c}-25.54 * * * \\
(6.85)\end{array}$ & $\begin{array}{l}-4.46 \\
(6.55)\end{array}$ & $\begin{array}{l}4.36 \\
(2.83)\end{array}$ & $\begin{array}{c}8.14^{* * *} \\
(2.40)\end{array}$ & $\begin{array}{c}13.47^{* * *} \\
(4.94)\end{array}$ & \\
\hline & Bad Health & $\begin{array}{l}-1.94 \\
(7.22)\end{array}$ & $\begin{array}{c}-90.74 * * * \\
(12.76)\end{array}$ & $\begin{array}{c}27.96^{* * *} \\
(7.54)\end{array}$ & $\begin{array}{c}3.74 * * * \\
(1.30)\end{array}$ & $\begin{array}{c}31.46^{* * *} \\
(8.85)\end{array}$ & $\begin{array}{c}19.83^{* *} \\
(8.47)\end{array}$ & $\begin{array}{l}-2.83 \\
(3.66)\end{array}$ & $\begin{array}{l}5.30^{*} \\
(3.10)\end{array}$ & $\begin{array}{c}5.13 \\
(6.38)\end{array}$ & \\
\hline$(N=3601)$ & Test of good $\&$ bad health & 0.105 & 0.000 & 0.000 & 0.005 & 0.000 & 0.012 & 0.090 & 0.003 & 0.023 & 0.000 \\
\hline \multirow{2}{*}{$\begin{array}{l}\text { All single } \\
\text { females, any } \\
\text { survey day }\end{array}$} & Good Health & $\begin{array}{l}-7.76 \\
(4.90)\end{array}$ & $\begin{array}{c}14.17^{* *} \\
(6.72)\end{array}$ & $\begin{array}{c}-12.00 * * * \\
(4.45)\end{array}$ & $\begin{array}{l}-1.79 \\
(1.22)\end{array}$ & $\begin{array}{c}-20.98^{* * *} \\
(4.84)\end{array}$ & $\begin{array}{l}1.21 \\
(4.51)\end{array}$ & $\begin{array}{c}6.16^{* * *} \\
(1.26)\end{array}$ & $\begin{array}{l}3.24 \\
(2.11)\end{array}$ & $\begin{array}{c}19.88^{* * *} \\
(4.27)\end{array}$ & \\
\hline & Bad Health & $\begin{array}{c}-32.14^{* * *} \\
(5.68)\end{array}$ & $\begin{array}{c}-33.53^{* * *} \\
(7.79)\end{array}$ & $\begin{array}{c}24.62^{* * *} \\
(5.16)\end{array}$ & $\begin{array}{c}4.69 * * * \\
(1.42)\end{array}$ & $\begin{array}{c}32.16^{* * *} \\
\quad(5.61)\end{array}$ & $\begin{array}{c}1.93 \\
(5.24)\end{array}$ & $\begin{array}{l}-1.47 \\
(1.46)\end{array}$ & $\begin{array}{c}9.26^{* * *} \\
(2.45)\end{array}$ & $\begin{array}{l}-1.54 \\
(4.95)\end{array}$ & \\
\hline$(N=6247)$ & Test of good $\&$ bad health & 0.000 & 0.000 & 0.000 & 0.000 & 0.000 & 0.943 & 0.000 & 0.001 & 0.000 & 0.000 \\
\hline
\end{tabular}

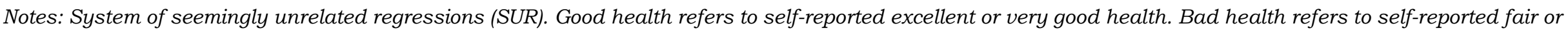

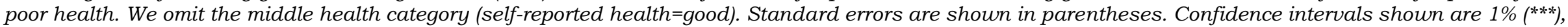

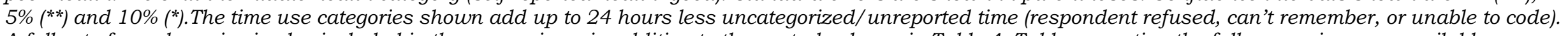

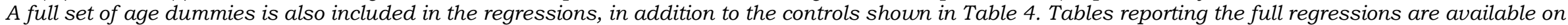
request. 
Table 6: Estimates of the effect of health status on various time use categories using HRS data

\begin{tabular}{|c|c|c|c|c|c|c|c|c|}
\hline & $\begin{array}{l}\text { Dependent variable: } \\
\text { Hours spent with } \\
\text { activity per week }\end{array}$ & $\begin{array}{l}\text { Home } \\
\text { Work }\end{array}$ & $\begin{array}{l}\text { Paid } \\
\text { Work }\end{array}$ & Sleep & Leisure & Exercise & $\begin{array}{c}\text { Grooming } \\
\text { and } \\
\text { Health } \\
\end{array}$ & $\begin{array}{l}\text { Other } \\
\text { Time } \\
\text { Uses } \\
\end{array}$ \\
\hline \multirow{4}{*}{$\begin{array}{l}\text { All single } \\
\text { males }\end{array}$} & Good Health & $\begin{array}{l}-0.02 \\
(0.78)\end{array}$ & $\begin{array}{c}0.15 \\
(0.38)\end{array}$ & $\begin{array}{c}2.07 * * * \\
(0.59)\end{array}$ & $\begin{array}{c}-2.71^{*} \\
(1.51)\end{array}$ & $\begin{array}{c}0.91^{* * *} \\
(0.33)\end{array}$ & $\begin{array}{c}-2.21^{* * *} \\
(0.35)\end{array}$ & $\begin{array}{l}1.67^{* *} \\
(0.77)\end{array}$ \\
\hline & Bad Health & $\begin{array}{l}-0.40 \\
(0.78)\end{array}$ & $\begin{array}{c}-0.68 * \\
(0.39)\end{array}$ & $\begin{array}{l}-0.16 \\
(0.64)\end{array}$ & $\begin{array}{c}6.42^{* * *} \\
(1.77)\end{array}$ & $\begin{array}{c}-1.91^{* * *} \\
(0.37)\end{array}$ & $\begin{array}{c}2.67^{* * *} \\
(0.41)\end{array}$ & $\begin{array}{l}0.50 \\
(0.90)\end{array}$ \\
\hline & $\mathrm{N}$ & 537 & 550 & 553 & 506 & 546 & 539 & 541 \\
\hline & Test of good \& bad health & 0.877 & 0.212 & 0.002 & 0.000 & 0.000 & 0.000 & 0.090 \\
\hline \multirow{4}{*}{$\begin{array}{l}\text { All single } \\
\text { females }\end{array}$} & Good Health & $\begin{array}{l}0.00 \\
(0.00)\end{array}$ & $\begin{array}{c}22.41^{* * *} \\
(0.10)\end{array}$ & $\begin{array}{c}25.38^{* * *} \\
(0.16)\end{array}$ & $\begin{array}{l}-1.01 \\
(0.94)\end{array}$ & $\begin{array}{c}0.71^{* * *} \\
(0.15)\end{array}$ & $\begin{array}{c}-1.07^{* * *} \\
(0.30)\end{array}$ & $\begin{array}{c}2.96 * * * \\
(0.56)\end{array}$ \\
\hline & Bad Health & $\begin{array}{c}-3.67 * * * \\
(0.42)\end{array}$ & $\begin{array}{c}-11.20^{* * *} \\
(0.11)\end{array}$ & $\begin{array}{c}-19.51^{* * *} \\
(0.24)\end{array}$ & $\begin{array}{l}0.30 \\
(0.89)\end{array}$ & $\begin{array}{c}-0.23 \\
(0.17)\end{array}$ & $\begin{array}{c}7.39 * * * \\
(0.35)\end{array}$ & $\begin{array}{r}-3.83 * * * \\
(0.53)\end{array}$ \\
\hline & $\mathrm{N}$ & 1697 & 1727 & 1727 & 1594 & 1705 & 1699 & 1683 \\
\hline & Test of good \& bad health & 0.000 & 0.000 & 0.000 & 0.554 & 0.000 & 0.000 & 0.000 \\
\hline
\end{tabular}

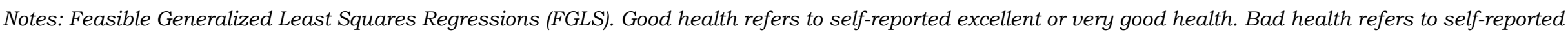

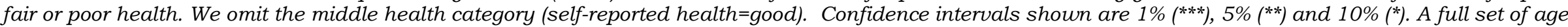

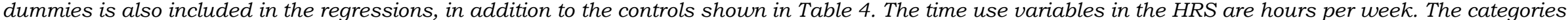
shown DO NOT add up to 168 hours per week. Tables reporting the full regressions are available on request. 
Table 7: Estimates of the effects of specific health conditions on various time use categories using HRS data

\section{MALES}

\begin{tabular}{|c|c|c|c|c|c|c|c|}
\hline $\begin{array}{l}\text { Dependent variable: } \\
\text { Hours spent with activity per week }\end{array}$ & $\begin{array}{l}\text { Home } \\
\text { Work }\end{array}$ & Paid Work & Sleep & Leisure & Exercise & $\begin{array}{c}\text { Grooming } \\
\text { and } \\
\text { Health } \\
\end{array}$ & $\begin{array}{l}\text { Other Time } \\
\text { uses }\end{array}$ \\
\hline high blood pressure & $\begin{array}{l}-4.79 * * * \\
(0.56)\end{array}$ & $\begin{array}{l}0.60^{* *} \\
(0.26)\end{array}$ & $\begin{array}{l}-0.25 \\
(0.38)\end{array}$ & $\begin{array}{c}7.50^{* * *} \\
(1.06)\end{array}$ & $\begin{array}{l}0.14 \\
(0.24)\end{array}$ & $\begin{array}{c}2.60^{* * *} \\
(0.27)\end{array}$ & $\begin{array}{l}0.67 \\
(0.54)\end{array}$ \\
\hline diabetes & $\begin{array}{c}-1.64^{* *} \\
(0.74)\end{array}$ & $\begin{array}{l}-0.01 \\
(0.31)\end{array}$ & $\begin{array}{c}-1.54^{* *} \\
(0.64)\end{array}$ & $\begin{array}{c}6.82^{* * *} \\
(1.43)\end{array}$ & $\begin{array}{l}-0.17 \\
(0.28)\end{array}$ & $\begin{array}{c}-2.86^{* * *} \\
(0.37)\end{array}$ & $\begin{array}{l}1.75^{*} \\
(0.92)\end{array}$ \\
\hline cancer & $\begin{array}{c}1.52 \\
(0.94)\end{array}$ & $\begin{array}{l}-0.18 \\
(0.29)\end{array}$ & $\begin{array}{c}1.98^{* * *} \\
(0.55)\end{array}$ & $\begin{array}{l}13.13^{* * *} \\
(1.79)\end{array}$ & $\begin{array}{l}-0.27 \\
(0.31)\end{array}$ & $\begin{array}{c}3.11^{* * *} \\
(0.55)\end{array}$ & $\begin{array}{c}4.45^{* * *} \\
(0.83)\end{array}$ \\
\hline lung disease & $\begin{array}{l}0.08 \\
(1.26)\end{array}$ & $\begin{array}{c}-0.77^{* *} \\
(0.33)\end{array}$ & $\begin{array}{c}0.22 \\
(0.51)\end{array}$ & $\begin{array}{c}5.83^{* * *} \\
(1.76)\end{array}$ & $\begin{array}{l}-1.51^{* * *} \\
(0.32)\end{array}$ & $\begin{array}{l}1.17^{* *} \\
(0.55)\end{array}$ & $\begin{array}{r}2.79^{* *} \\
(1.13)\end{array}$ \\
\hline heart disease & $\begin{array}{l}1.13 \\
(0.73)\end{array}$ & $\begin{array}{l}0.10 \\
(0.26)\end{array}$ & $\begin{array}{c}-1.63^{* * *} \\
(0.50)\end{array}$ & $\begin{array}{l}3.02^{* *} \\
(1.34)\end{array}$ & $\begin{array}{l}-0.07 \\
(0.26)\end{array}$ & $\begin{array}{c}1.25^{* * *} \\
(0.37)\end{array}$ & $\begin{array}{c}4.71^{* * *} \\
(0.71)\end{array}$ \\
\hline stroke & $\begin{array}{c}-3.03^{* * *} \\
(1.09)\end{array}$ & $\begin{array}{c}-0.96^{* * *} \\
(0.35)\end{array}$ & $\begin{array}{l}2.23^{* *} \\
(0.88)\end{array}$ & $\begin{array}{c}-4.58^{* * *} \\
(1.74)\end{array}$ & $\begin{array}{c}-2.19^{* * *} \\
(0.37)\end{array}$ & $\begin{array}{c}-2.95^{\star * *} \\
(0.51)\end{array}$ & $\begin{array}{c}-1.83^{*} \\
(1.11)\end{array}$ \\
\hline psychiatric problems & $\begin{array}{c}-2.53^{* * *} \\
(0.94)\end{array}$ & $\begin{array}{c}-1.57^{* * *} \\
(0.34)\end{array}$ & $\begin{array}{l}1.15^{* *} \\
(0.53)\end{array}$ & $\begin{array}{c}-3.10^{*} \\
(1.64)\end{array}$ & $\begin{array}{l}-0.48 \\
(0.30)\end{array}$ & $\begin{array}{c}9.50^{* * *} \\
(0.43)\end{array}$ & $\begin{array}{c}6.50^{* * *} \\
(0.97)\end{array}$ \\
\hline arthritis & $\begin{array}{c}2.26^{* * *} \\
(0.56)\end{array}$ & $\begin{array}{c}-1.77^{* * *} \\
(0.29)\end{array}$ & $\begin{array}{l}-0.60 \\
(0.41)\end{array}$ & $\begin{array}{c}3.30^{* * *} \\
(1.01)\end{array}$ & $\begin{array}{c}-0.82^{* * *} \\
(0.23)\end{array}$ & $\begin{array}{c}0.86^{* * *} \\
(0.28)\end{array}$ & $\begin{array}{c}0.92 \\
(0.56)\end{array}$ \\
\hline $\mathrm{N}$ & 535 & 547 & 550 & 504 & 543 & 536 & 538 \\
\hline
\end{tabular}

Notes: Feasible Generalized Least Squares Regressions (FGLS). Confidence intervals shown are 1\%(***), 5\%(**) and $10 \%(*)$. A full set of age dummies is also included in the regressions, in addition to the controls shown in Table 4. The time use variables in the HRS are hours per week. The categories shown DO NOT add up to 168 hours per week. Tables reporting the full regressions are available on request. 
Table 8: Estimates of the effects of specific health conditions on various time use categories using HRS data

\section{FEMALES}

\begin{tabular}{|c|c|c|c|c|c|c|c|}
\hline $\begin{array}{l}\text { Dependent variable: } \\
\text { Hours spent with activity per week }\end{array}$ & $\begin{array}{l}\text { Home } \\
\text { Work }\end{array}$ & Paid Work & Sleep & Leisure & Exercise & $\begin{array}{c}\text { Grooming } \\
\text { and } \\
\text { Health }\end{array}$ & $\begin{array}{c}\text { Other Time } \\
\text { uses }\end{array}$ \\
\hline high blood pressure & $\begin{array}{l}-1.60 * * * \\
(0.28)\end{array}$ & $\begin{array}{c}-0.37^{* * *} \\
(0.07)\end{array}$ & $\begin{array}{l}0.62^{* * *} \\
(0.17)\end{array}$ & $\begin{array}{l}-0.64 \\
(0.60)\end{array}$ & $\begin{array}{c}-0.27^{* *} \\
(0.11)\end{array}$ & $\begin{array}{c}-0.43^{* * *} \\
(0.16)\end{array}$ & $\begin{array}{r}0.85^{* *} \\
(0.35)\end{array}$ \\
\hline diabetes & $\begin{array}{c}-0.88^{* *} \\
(0.39)\end{array}$ & $\begin{array}{c}-1.12^{* * *} \\
(0.09)\end{array}$ & $\begin{array}{c}-1.30 * * * \\
(0.25)\end{array}$ & $\begin{array}{c}3.07 * * * \\
(0.77)\end{array}$ & $\begin{array}{l}-1.03 * * * \\
(0.13)\end{array}$ & $\begin{array}{c}2.31^{* * *} \\
(0.33)\end{array}$ & $\begin{array}{c}2.07 * * * \\
(0.47)\end{array}$ \\
\hline cancer & $\begin{array}{l}1.49 * * * \\
(0.45)\end{array}$ & $\begin{array}{l}-0.08 \\
(0.09)\end{array}$ & $\begin{array}{c}1.35^{* * *} \\
(0.23)\end{array}$ & $\begin{array}{r}2.37 * * \\
(0.95)\end{array}$ & $\begin{array}{c}0.90 * * * \\
(0.17)\end{array}$ & $\begin{array}{c}-1.39 * * * \\
(0.23)\end{array}$ & $\begin{array}{c}-0.90 * * \\
(0.45)\end{array}$ \\
\hline lung disease & $\begin{array}{c}3.02^{* * *} \\
(0.44)\end{array}$ & $\begin{array}{c}-1.31^{* * *} \\
(0.12)\end{array}$ & $\begin{array}{c}0.03 \\
(0.30)\end{array}$ & $\begin{array}{c}3.69 * * * \\
(1.19)\end{array}$ & $\begin{array}{c}0.13 \\
(0.15)\end{array}$ & $\begin{array}{c}2.81^{* * *} \\
(0.54)\end{array}$ & $\begin{array}{l}1.20^{*} \\
(0.65)\end{array}$ \\
\hline heart disease & $\begin{array}{l}0.53 \\
(0.36)\end{array}$ & $\begin{array}{c}-0.34^{* * *} \\
(0.08)\end{array}$ & $\begin{array}{c}0.46^{* *} \\
(0.21)\end{array}$ & $\begin{array}{c}0.99 \\
(0.77)\end{array}$ & $\begin{array}{c}0.56^{* * *} \\
(0.13)\end{array}$ & $\begin{array}{c}0.84^{* * *} \\
(0.19)\end{array}$ & $\begin{array}{c}3.90^{* * *} \\
(0.43)\end{array}$ \\
\hline stroke & $\begin{array}{c}-3.75^{* * *} \\
(0.49)\end{array}$ & $\begin{array}{c}-0.68^{* * *} \\
(0.19)\end{array}$ & $\begin{array}{c}-1.63^{* * *} \\
(0.32)\end{array}$ & $\begin{array}{c}-14.11^{* * *} \\
(1.13)\end{array}$ & $\begin{array}{c}-0.40 * * \\
(0.19)\end{array}$ & $\begin{array}{c}-0.79 * * * \\
(0.29)\end{array}$ & $\begin{array}{c}-4.00^{* * *} \\
(0.61)\end{array}$ \\
\hline psychiatric problems & $\begin{array}{c}4.74^{* * *} \\
(0.36)\end{array}$ & $\begin{array}{c}-1.12^{* * *} \\
(0.09)\end{array}$ & $\begin{array}{c}0.33 \\
(0.22)\end{array}$ & $\begin{array}{c}6.61^{* * *} \\
(0.65)\end{array}$ & $\begin{array}{c}0.93^{* * *} \\
(0.11)\end{array}$ & $\begin{array}{c}2.74 * * * \\
(0.27)\end{array}$ & $\begin{array}{c}2.19 * * * \\
(0.40)\end{array}$ \\
\hline arthritis & $\begin{array}{l}-0.41 \\
(0.26)\end{array}$ & $\begin{array}{c}-1.22^{* * *} \\
(0.10)\end{array}$ & $\begin{array}{c}-1.00^{* * *} \\
(0.18)\end{array}$ & $\begin{array}{l}1.11^{* *} \\
(0.55)\end{array}$ & $\begin{array}{c}0.40^{* * *} \\
(0.11)\end{array}$ & $\begin{array}{c}1.29 * * * \\
(0.16)\end{array}$ & $\begin{array}{c}-1.26^{* * *} \\
(0.39)\end{array}$ \\
\hline $\mathrm{N}$ & 1692 & 1722 & 1724 & 1587 & 1701 & 1696 & 1678 \\
\hline
\end{tabular}

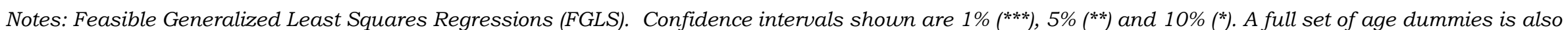

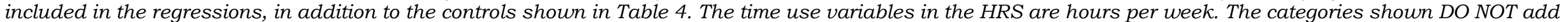
up to 168 hours per week. Tables reporting the full regressions are available on request. 
Table 9: Estimates of the effect of health status on money spent on various services using HRS data

\begin{tabular}{|c|c|c|c|c|c|}
\hline & $\begin{array}{c}\text { Dependent variable: } \\
\text { Dollars spent on service } \\
\text { per year }\end{array}$ & $\begin{array}{c}\text { Housekeeping } \\
\text { services }\end{array}$ & Yard services & Dining out & $\begin{array}{c}\text { Housekeeping, } \\
\text { yard, and dining } \\
\text { services } \\
\end{array}$ \\
\hline \multirow{4}{*}{ All single males } & Good Health & $\begin{array}{c}-166.97^{* * *} \\
(19.00)\end{array}$ & $\begin{array}{c}70.56^{* * *} \\
(6.68)\end{array}$ & $\begin{array}{c}-255.98^{* * *} \\
(69.24)\end{array}$ & $\begin{array}{c}-383.93^{* * *} \\
(89.72)\end{array}$ \\
\hline & Bad Health & $\begin{array}{l}979.60^{* * *} \\
(0.00)\end{array}$ & $\begin{array}{c}0.00 \\
(0.00)\end{array}$ & $\begin{array}{c}244.90 * * * \\
(0.00)\end{array}$ & $\begin{array}{c}1224.50 * * * \\
(0.00)\end{array}$ \\
\hline & $\mathrm{N}$ & 506 & 499 & 501 & 490 \\
\hline & Test of good \& bad health & 0.000 & 0.000 & 0.000 & 0.000 \\
\hline \multirow{4}{*}{ All single females } & Good Health & $\begin{array}{c}35.59 * * * \\
(7.58)\end{array}$ & $\begin{array}{c}-23.15^{* *} \\
(9.18)\end{array}$ & $\begin{array}{c}168.92^{* * *} \\
(18.13)\end{array}$ & $\begin{array}{c}130.14^{* * *} \\
(29.28)\end{array}$ \\
\hline & Bad Health & $\begin{array}{c}-62.74 * * * \\
(7.24)\end{array}$ & $\begin{array}{l}74.95^{* * *} \\
(9.12)\end{array}$ & $\begin{array}{c}-120.87^{* * *} \\
(18.49)\end{array}$ & $\begin{array}{c}-132.15^{* * *} \\
(33.02)\end{array}$ \\
\hline & $\mathrm{N}$ & 1632 & 1635 & 1631 & 1601 \\
\hline & Test of good \& bad health & 0.000 & 0.000 & 0.000 & 0.000 \\
\hline
\end{tabular}

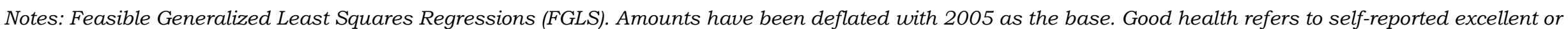

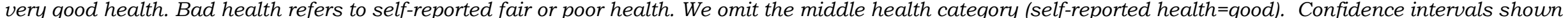

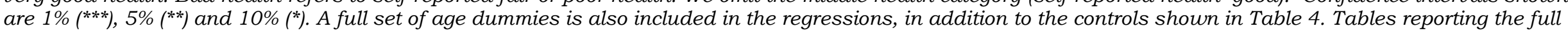
regressions are available on request. 